\title{
Effect of Formula Fertilization Technology Subsidy Policy on Rice Production in China: A Case of Xinyang City
}

Jiarong Qian (Kyushu University, Graduate School of Bioresource and Bioenvironmental Sciences) Shoichi Ito (Kyushu University, Graduate School of Bioresource and Bioenvironmental Sciences)

Yueying $\mathrm{Mu}$ (China Agricultural University, College of Economics and Management)

Hiroshi Isoda (Kyushu University, Graduate School of Bioresource and Bioenvironmental Sciences) Hisamitsu Saito (Kyushu University, Graduate School of Bioresource and Bioenvironmental Sciences)

\section{配合施肥技術開発補助政策が中国の稲作生産の効率性に与える効果}

\author{
銭加栄（九州大学大学院生物資源環境学府) \\ 伊東 正一（九州大学大学院生物資源環境学府） \\ 穆月英（中国农业大学经济管理学院） \\ 磯田宏（九州大学大学院生物資源環境学府) \\ 齋藤 久光（九州大学大学院生物資源環境学府）
}

中国では化学肥料や農薬の過度な使用が環境 へ及ぼす効果が問題視され，肥料投入を適切に 管理する配合施肥技術が注目されている。しか し，高額な費用がその普及の妨げとなっている ことから, 中国政府は普及を目的とした補助事 業を2005 年に開始した。そこで本論文では DEA

\section{Introduction}

Excessive use of chemical fertilizers and pesticides causes environment deterioration in China. A series of technical subsidy policies have been implemented to extend new agricultural and environmental technology since 2005. Formula fertilization technology is a well known example. It consists of field investigation, soil sample collection, field experiment, formula design, fertilizer making, and technical support. This technology aims to protect agricultural environment, reduce costs and enhance production efficiency, but has large costs to be implemented. To diffuse this technology, the formula fertilization technology subsidy policy was introduced in 2005. Since then, its effects on environment and agricultural productivity have received much attention from academics and policy makers. For example, Zhang (2009) employed positive mathematical programming (PMP) method to assess the effect of formula fertilization technology in Jiangsu province and found that the formula
を援用し，補助事業が中国の稲作生産の効率性 に与える影響の定量的な評価を行った。分析の 結果，全ての分析対象地に打いて生産効率が格 段に向上して括り，また生産要素の使用が効率 化されていることから補助事業の有効性が確認 された。

fertilization technology helped increase farmers' income. Qu and Guo (2010), Mu and Duan (2009), Wang (2007) and Ying and $\mathrm{Yu}$ (2006) compared the fertilizer usage and crop production before and after the technology adoption using field experiments. They found the fertilizer usage has decreased while the production has increased. However, few of them have studied how technical efficiency in crop production has changed due to the subsidy. To fill this gap in the literature, we take Xinyang city as a case and employ Data Envelopment Analysis (DEA) to assess the effect of formula fertilization subsidy policy on technical efficiency in crop production ${ }^{1)}$.

\section{Methodology and Data}

DEA is a mathematical programming approach to estimate the relative efficiency of each decision making unit (DMU). It has been widely used in agricultural economics (e.g. Francisco et al, (2010)). The efficiency of a particular DMU is obtained by maximizing a ratio of weighted 
outputs to weighted inputs:

$$
\max _{u, v} E=u^{T} y_{0} / v^{T} x_{0},
$$

subject to $u^{T} y_{i} / v^{T} x_{i} \leq 1, i=1,2, \ldots, n, u \geq 0, v \geq 0$, where $u=\left(u_{1}\right.$, $\left.u_{2}, \ldots, u_{s}\right)^{T}, v=\left(v_{1}, v_{2}, \ldots, v_{m}\right)^{T}$ are weighting parameters for $s$ outputs and $m$ inputs, respectively; $y$ and $x$ represent outputs and inputs; $n$ indicates the number of the DMUs; The subscript zero indicates the particular DMU to be evaluated.

The above model yields two production indices: (i) technical efficiency and (ii) input excess ${ }^{2}$. Figure 1 illustrates how technical efficiency and input excess are measured by DEA. Suppose two inputs $\mathrm{x}_{1}$ and $\mathrm{x}_{2}$ are used to produce a single output $\mathrm{y}$. $\mathrm{SS}_{1}$ is a unit isoquant. $\mathrm{DMU}$ at point $\mathrm{P}$ is not efficient in its production because it is located at the above of the isoquant. Its (i) efficiency value $E$ is defined by $\mathrm{OP}_{1} / \mathrm{OP}$, where $\mathrm{P}_{1}$ is its efficient production level. Hence, $E$-value takes between zero and one. When $E$ equals to one, DMU's production is efficient and is located on a frontier of the isoquant. On the contrary, resources are not efficiently used if $E$ is smaller than one: the smaller $E$ is, the less efficient the production is. Next, (ii) input excess measures how much inputs can be reduced without changing the output quantities. Namely, $\mathrm{MM}_{1}$ and $\mathrm{NN}_{1}$ measure input excesses, i.e. how much $\mathrm{x}_{1}$ and $\mathrm{x}_{2}$ can be reduced if production takes place at $\mathrm{P}_{1}$ on the isoquant. In other words, input excess is observed only if a DMU is not on a production frontier. Larger input excess reflects worse production technology and a decline in input excess implies an improvement in the technology.

Note that targets of this subsidy are counties, not farmers. The funds are subsidized to the department of agricultural extension in each county, and the department uses the subsidy to provide technical services for farmers for free. With technical services such as soil sample collection and formula design, farmers can realize the soil condition of their fields and appropriately control the amount of fertilizers. In 2005, 200 counties were subsidized, and its number has increased annually. Until 2009, 2498 counties were covered by the subsidy policy and four billion yuan had been spent for this purpose.

Xinyang city is a major rice production area in Henan province, which produces more than $80 \%$ of rice of Henan province, and in 2010 its rice production reached to 4129 thousand tons. The formula fertilization technology subsidy has been introduced in this area since 2006. Table 1 summarizes the total amount of the subsidy and a starting

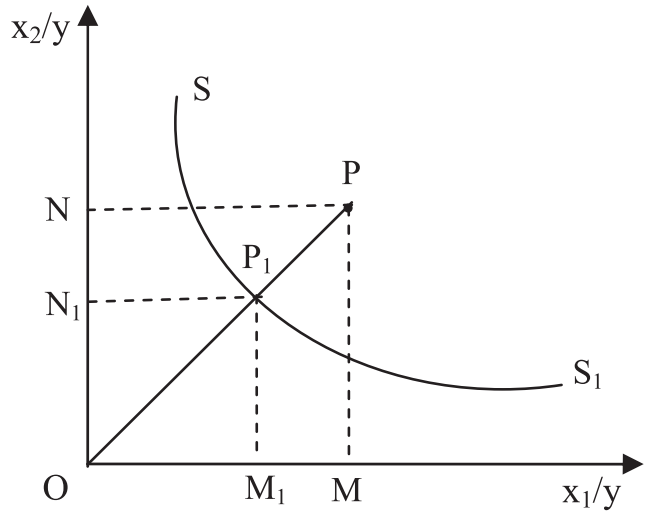

Fig. 1. Technical efficiency and input excess Source: Farrell (1957).

Table 1. Total subsidy funds in each county

\begin{tabular}{ccc}
\hline \hline County & $\begin{array}{c}\text { Subsidy } \\
\text { (million yuan) }\end{array}$ & Starting Year \\
\hline Gushi & 2.5 & 2006 \\
Xixian & 2.5 & 2006 \\
Shangcheng & 2.0 & 2007 \\
Pingqiao & 1.5 & 2008 \\
\hline
\end{tabular}

Source: Authors' investigation. Note: Values in subsidy are cumulative to 2009 from the starting years.

year for each studied area. Each county in general receives one million yuan in the first year and 0.5 million yuan for the following years.

Formula fertilization technology reduces wastes in crop production by efficiently using fertilizers. Data on three inputs related to this technology, i.e. seed $(\mathrm{kg} / \mathrm{mu})$, fertilizer $(\mathrm{kg} / \mathrm{mu})$, and pesticide (yuan/mu) and two outputs, yields $(\mathrm{kg} / \mathrm{mu}$ ) and net returns (yuan/mu), are collected from Cost and Return of Agricultural Commodities Yearbook in Henan Province for 2003 to 2008 (one mu is equivalent to $0.067 \mathrm{ha}$ ). Data for each region is averaged for two periods: before and after the subsidy implementation. This yields eight DMUs, i.e. two DMUs for each county.

\section{Estimation Results}

\section{(1) Analysis on Technical Efficiency}

Table 2 shows changes in $E$-value in four counties. They are respectively 0.709 and 0.885 in Pingqiao and Shangcheng counties before the subsidy implementation. After the subsidy is implemented, $E$-values in both counties reach to one and production in these counties takes 
Table 2. Changes in technical efficiency before and after the subsidy implementation

\begin{tabular}{|c|c|c|c|c|}
\hline \multirow{2}{*}{ County } & \multicolumn{2}{|c|}{$E$-value } & \multirow{2}{*}{ Change } & \multirow{2}{*}{$\begin{array}{l}\text { Percent } \\
\text { Change }\end{array}$} \\
\hline & Before & After & & \\
\hline Pingqiao & 0.709 & 1.000 & 0.291 & 41.0 \\
\hline Shangcheng & 0.885 & 1.000 & 0.115 & 13.0 \\
\hline Gushi & 0.902 & 0.957 & 0.055 & 6.1 \\
\hline Xixian & 0.513 & 0.830 & 0.317 & 61.8 \\
\hline
\end{tabular}

Source: Authors' calculations.

Table 3. Changes in input excesses before and after the subsidy implementation

\begin{tabular}{lcccc}
\hline \hline County & Before & After & Change & $\begin{array}{c}\text { Percent } \\
\text { Change }\end{array}$ \\
\hline Pingqiao & 0.42 & 0.00 & -0.42 & -100.0 \\
Shangcheng & 0.13 & 0.00 & -0.13 & -100.0 \\
Gushi & 0.11 & 0.04 & -0.07 & -63.6 \\
Xixian & 0.85 & 0.18 & -0.67 & -78.8 \\
& & Fertilizer $(\mathrm{kg} / \mathrm{mu})$ & \\
Pingqiao & 3.95 & 0.00 & -3.95 & -100.0 \\
Shangcheng & 1.63 & 0.00 & -1.63 & -100.0 \\
Gushi & 1.02 & 0.62 & -0.40 & -39.2 \\
Xixian & 9.07 & 3.77 & -5.30 & -58.4 \\
& & Pesticide $(\mathrm{yuan} / \mathrm{mu})$ & \\
Pingqiao & 1.77 & 0.00 & -1.77 & -100.0 \\
Shangcheng & 5.19 & 0.00 & -5.19 & -100.0 \\
Gushi & 3.15 & 2.69 & -0.46 & -14.6 \\
Xixian & 10.31 & 28.31 & 18.00 & 174.6 \\
\hline
\end{tabular}

Source: Authors' calculations.

place on a production frontier. $E$-value for Gushi is 0.902 before the subsidy, and reaches to 0.957 after the subsidy. Rice is least efficiently produced in Xixian. However, the region shows the largest increase in $E$-value after the subsidy. It rises up to 0.830 , an increase by 61.8 percent. As a result, $E$-values have increased after the subsidy implementation in all four counties.

\section{(2) Analysis on Input Excesses}

The inputs excess values for each county are listed in Table 3. For example, the average farmers in Pingqiao county can reduce $0.42 \mathrm{~kg}$ of seeds, $3.95 \mathrm{~kg}$ of fertilizer, and 1.77 yuan of pesticide without changing the outputs quantities before the subsidy is implemented. All input excesses become zero after the subsidy because its production takes place on the frontier after the subsidy implementation (table 2). In Shangcheng county, excess in fertilizer also becomes zero after the subsidy implementation. In Gushi and Xixian counties, excesses in fertilizer drop by $0.4 \mathrm{~kg} / \mathrm{mu}$ and $5.3 \mathrm{~kg} / \mathrm{mu}$, corresponding to a $39.2 \%$ and a $58.4 \%$ decrease, respectively. This result shows the formula fertilization technology subsidy is effective in reducing fertilizer usage in four counties.

We also find excesses in seeds and pesticide have decreased in most counties. In Gushi county, excesses in seeds and pesticide drop by $63.6 \%$ and $14.6 \%$, respectively, after the subsidy implementation. In Xixian county, excess in seeds decreases by $78.8 \%$ while excess in pesticide increases by $174.6 \%$. This last finding may reflect pest disasters happened in this area during the period.

\section{Conclusions}

Employing Data Envelope Analysis, we assess the effect of the formula fertilization technology subsidy policy on technical efficiency in rice production in China. Results show technical efficiency significantly increases in every county after the subsidy implementation, implying the effectiveness of the technical subsidy. Secondly, fertilizer excesses become small after the subsidy implementation, indicating this new technology significantly improves farmers' resource utilization. As a conclusion, Chinese government should enlarge the geographical coverage of the subsidy to diffuse this technology nationwide.

\section{Notes}

1) The study was funded by the Mode Construction of Modern Farming System and Supporting Technology Research and Demonstration, China (201103001).

2) See Charnes et al (1978), Wei et al (1989), and Wei (2001) for the detailed estimation procedures and formulas of these indices. We focus on technical efficiency in this paper because data on input prices are not available at county level and our interest lies in how much inputs can be saved, that is how much the overuse of fertilizer is reduced, by the policy.

\section{References}

[1] C. Y. Zhang and H. F. Xiao, "Evaluation on Economic Effect of Soil Testing Technology in Jiangsu Province”, Technology Economics, 4(2009), p. 66-70. 
[2] M. S. Qu and N. Guo, "Effect of Formula Fertilization Technology in Beijing City”, China Agricultural Technology Extension, 26(2010), p. 34-36.

[3] S. H. Mu and J. S. Duan, "Effect of Formula Fertilization Technology on Wheat Production in Hubei Province”, Modern Agricultural Science and Technology, 10(2010), p. 54-55.

[4] F. S. Wang, "Applied effect of formula fertilization technology on rice production", Modern Agricultural Science and Technology, 10(2007), p. 109-110.

[5] X. G. Ying and Z. G. Yu, "Analysis on Effect of Formula Fertilization Technology on Rice Production”, Acta Agriculturae Jiangxi, 18(2006), p. 52-53.
[6] J. Francisco, Andre, H. Ines, and R. Laura, "A Modified DEA Model to Estimate the Importance of Objectives with an Application to Agricultural Economics”, Omega, 38(2010), p. 371-382.

[7] A. Charnes, W. W. Cooper, and E. Rhodes, "Measuring the efficiency of decision making units", European Journal of Operational Research, 2(1978), p. 429-444.

[8] Q. L. Wei, "Data Envelopment Analysis", Chinese Science Bulletin, 46(2001), p. 1321-1330.

[9] Q. L. Wei and G. Lu, "Application of DEA Method and Model", Systems Engineeringtheory \&Practice, 3(1989), p. 67-75.

[10] M. J. Farrell, "The Measurement of Productive Efficiency", Journal of the Royal Statistical Society, 120(1957), p. 253-281.

（受理日：2012 年 3 月 1 日） 